Agata Kubec iDhttps://orcid.org/0000-0002-7131-1637

Uniwersytet Jagielloński

e-mail: agata.kubec@gmail.com

Otrzymano/Received: 15.09 .2020

Zaakceptowano/Accepted: 4.11.2020

Opublikowano/Published: 11.12.2020

\title{
Uświadomiona i nieuświadomiona postać cienia organizacyjnego w komercyjnej organizacji medialnej
}

\section{Abstract \\ A Conscious and Unconscious Form of Organizational Shadow in a Commercial Media Organization}

The aim of the article is to explore and describe the organizational shadow in relation to the commercial media institution. The concept of shadow was introduced by Jung, who described it as the negative side of the human soul. As Bowles noted in 1991, this phenomenon can be applied to management sciences. The organizational shadow is created as a result of rejecting difficult, defective and uncomfortable elements of the institution's identity, which can lead to the development of management pathologies. Interviews, which are the domain of qualitative methodology, allowed to distinguish organizational shadows in the commercial radio station, taking into account the causes and effects of their development as well as awareness of their existence among employees. The shadows include: unequal treatment of volunteer workers, giving up the development of young radio broadcasters, as well as a unjust remuneration policy. The conclusion of the article is indication the brand myth as the main reason for allowing the development of shadows.

Keywords: organizational shadow, commercial radio, management pathologies, identification with brand, organizational identity

Słowa kluczowe: cień organizacyjny, komercyjne radio, patologie organizacji, identyfikacja z marką, tożsamość organizacji 


\section{Wprowadzenie}

Niniejszy artykuł jest próbą eksploracji zjawiska określanego jako „cień organizacyjny”. Celem autorki jest odkrycie, czy członkowie dużej komercyjnej stacji radiowej mają świadomość istnienia cienia, rozumianego jako negatywne aspekty firmy, wypierane przez ogół. Artykuł ma pokazać, czy przeciętni pracownicy zwracają na nie uwagę oraz czy, wiedząc o ich istnieniu, mimo wszystko próbują ukrywać je w kontaktach z zewnętrznymi podmiotami, tworząc tym samym iluzję organizacji idealnej.

Na gruncie nauk o zarządzaniu cień odnosi się do funkcjonowania całych organizacji. Powstaje wskutek intensywnych dążeń do perfekcjonizmu i do uzyskania społecznej aprobaty. Potrzeba wyeliminowania absolutnie wszystkich negatywnych aspektów działania i przekonanie o braku ograniczeń sprawia, że organizacje nie radzą sobie ze swoją naturalną ułomnością, co prowadzi do wewnętrznego niepokoju, a także obwiniania zewnętrznych podmiotów o wszystkie błędy i niepowodzenia. Zjawisko to potęguje fakt, że współczesne organizacje bardziej niż do budowania dojrzałej, świadomej tożsamości dążą do kreowania idealnego wizerunku - tak bardzo pożądanej w dzisiejszych czasach marki. Marka jest pojęciem abstrakcyjnym, wyrażającym przywiązanie emocjonalne; to odzwierciedlenie wartości, stylu życia, pożądanych postaw (Sempruch-Krzemińska 2014, s. 80-82). Marka przyciąga potencjalnych pracowników, klientów i inwestorów, przez co praca nad jej nieskazitelnym obrazem stała się dużo ważniejsza niż rzeczywista statutowa działalność firm, związana z wytwarzaniem produktów bądź usług. Jednak życie w iluzji idealnego systemu nie sprawi, że problemy rzeczywiście przestaną istnieć. Wręcz przeciwnie będą się namnażać.

Wypieranie negatywnych aspektów i spychanie ich w sferę nieświadomości prowadzi do zjawiska błędnego koła. Naturalnymi przyczynami rozwoju i wzmacniania cienia są: nadmierna kontrola, niedbałość oraz przemoc (Kostera 2010, s. 78). Ich istnienie świadczy także o tym, że organizacja już posiada rozwinięty cień. Nawarstwianie się cienia i próba ukrycia coraz to poważniejszych problemów to złożone zjawisko, które nie może zostać zatrzymane, dopóki członkowie organizacji nie uświadomią sobie, że cień jest powszechny i nie da się go usunąć, a jedynym rozwiązaniem jest zaakceptowanie go w procesie integracji (Kostera 2010, s. 82).

Choć cień organizacyjny jest zjawiskiem, które pojawia się w literaturze przedmiotu już od ostatniej dekady XX wieku, to wciąż jest to nie do końca odkryta dziedzina. Badacze zwracają głównie uwagę na sam cień, omawiając fazy jego rozwoju i skutki, do jakich może prowadzić. Niniejszy artykuł, oprócz wskazania cieni organizacyjnych istniejących w dużej komercyjnej organizacji medialnej, skupia się na postrzeganiu ich przez przeciętnych pracowników, na przyczynach jego powstania i powodach, dla których cień spychany jest do nieświadomości. Czy pracownicy zwracają uwagę na ciemne strony organizacji? Czy komunikują na zewnątrz swoje refleksje z tym związane? Czy dopuszczalne są otwarte dyskusje o ciemnych stronach? Czy może 
wręcz przeciwnie - pracownicy żyją w iluzji idealnej organizacji i starają się robić wszystko, żeby tę iluzję podtrzymywać? Dlaczego pomimo zdawania sobie sprawy $\mathrm{z}$ istnienia cienia pracownicy pozostawiają go $\mathrm{w}$ sferze nieświadomości? To pytania badawcze, na które odpowiedzi stara się udzielić prezentowany artykuł, próbując tym samym zgłębić temat świadomości cienia organizacyjnego w instytucji medialnej i wypełnić lukę badawczą w tym zakresie. Eksploracja tematyki cienia jest tak istotna $\mathrm{z}$ uwagi na fakt, że zjawisko to dotyczy każdej organizacji i może prowadzić do poważnych dysfunkcji w jej działaniu, a także w sposób znaczący rzutować na jej pracowników. Badania przeprowadzone w ramach artykułu mogą stanowić punkt wyjścia do dalszych rozważań w obszarze teorii organizacji, patologii zarządzania, sposobów zarządzania kulturą organizacyjną czy polityki wynagrodzeń pracowników.

\section{Cien organizacyjny w literaturze przedmiotu}

Archetyp cienia został wyróżniony przez Carla Gustava Junga (1976), który odnosił go do natury ludzkiej i opisywał jako składnik osobowości każdego człowieka - jego integralną i nieodłączną część, wiążącą się z cechami niechcianymi, nieakceptowanymi, powszechnie uważanymi za złe, za takie, które należy wyeliminować w procesie socjalizacji.

Choć pierwotna koncepcja cienia odnosi się do człowieczeństwa, to można ją także zastosować w nauce o organizacji. Zauważył to Martin L. Bowles (1991), który jako pierwszy przeniósł omawiany archetyp na grunt nauk o zarządzaniu. W artykule The Organizational Shadow Bowles określa cień jako te cechy organizacji, które ona sama chce wyeliminować, żeby utrzymywać nieskazitelny wizerunek. Badacz zauważył, że cień może rozwijać się w ukryciu jedynie do pewnego momentu i że ignorowanie go prowadzi do jego eksplozji w najmniej oczekiwanym momencie. Tematowi omawianego archetypu przyglądał się także Adrian Carr (2002), który zwrócił szczególną uwagę na zależność pomiędzy nadmierną kontrolą, mającą za zadanie ulepszanie organizacji, a „wielkością” cienia; im większa kontrola, tym ciemne strony organizacji są coraz bardziej złożone. W Polsce na temat cienia organizacyjnego najwięcej do powiedzenia ma zdecydowanie Monika Kostera, która opisywała to zjawisko w następujących pozycjach: Experiencing the Shadow: Organizational Exclision and Denial within Experience Economy (Kociatkiewicz, Kostera 2010) oraz Organizacje i archetypy (Kostera 2010). Badaczka wraz z Jerzym Kociatkiewiczem stworzyła model powstawania cienia organizacyjnego, oparty na modelu tworzenia tożsamości. Schemat ten podkreśla, że w procesie tworzenia się cienia, tak jak w procesie kształtowania świadomej tożsamości, pewne realnie przestrzegane wartości są uznawane za niezgodne z kanonem, a następnie odrzucane i zastępowane wartościami deklarowanymi. 


\section{Metodologia badań}

Niniejszy artykuł opiera się na analizie i zrozumieniu zjawiska cienia organizacyjnego występującego w dużej komercyjnej rozgłośni radiowej. Do badania wybrano jedną z największych instytucji medialnych w Polsce, odnotowującą wysoki udział zarówno w rynku medialnym, jak i reklamowym. Badania przeprowadzone zostały w nurcie humanistycznym w naukach o zarządzaniu przy zastosowaniu jakościowych metod badawczych, które cechuje uwzględnienie perspektyw różnych aktorów społecznych danej organizacji, co prowadzić ma do jak najwierniejszego opisu wycinka rzeczywistości społecznej. Kategorią światopoglądową stanowiącą bazę przeprowadzonych badań jest paradygmat interpretatywny, wyróżniony przez Burella oraz Morgana jako jeden z czterech charakterystycznych dla nauk o zarządzaniu (Burell, Morgan 1979, s. 28). U jego podstaw leży przekonanie, że rzeczywistości nie da się obiektywnie poznać, ponieważ jest ona „intersubiektywnym tworem uczestników, czyli ludzi żyjących w świecie społecznym" (Kostera 1996, s. 34).

Proces badawczy rozpoczął się 20 lutego 2020 r. badaniem pilotażowym, które przybrało formę etnografii wirtualnej mającej na celu wstępne rozpoznanie tematu oraz wyróżnienie potencjalnych cieni, jakie mogą występować w rozgłośni radiowej. Jednym z elementów badania była analiza strony internetowej radia oraz jego profili w mediach społecznościowych, co doprowadziło do poznania wartości deklarowanych przez rozgłośnię. Ponadto analizie poddane zostały wszelkiego rodzaju fora dyskusyjne, na których byli i obecni członkowie organizacji wyrażają swoje opinie na temat instytucji jako miejsca pracy. Badanie pilotażowe pozytywnie wpłynęło na proces projektowania wywiadów, stanowiących główną metodę badawczą.

W celu eksploracji zjawiska cienia organizacyjnego w badanej organizacji przeprowadzono 7 wywiadów o charakterze nieustrukturyzowanym i niestandaryzowanym, określanych także jako swobodne, otwarte bądź antropologiczne (Kostera 2003, s. 122). Wywiady są jedną z podstawowych metod w badaniach jakościowych, a także głównym sposobem gromadzenia informacji w naukach społecznych (Gudkova 2012, s. 111). W rozmowach wzięło udział siedmioro pracowników badanej instytucji medialnej, których staż pracy wynosi od roku do pięciu lat. Aby możliwie jak najobiektywniej wniknąć w organizacyjny świat, wybrani pracownicy reprezentują różne stanowiska, zarówno pod kątem hierarchicznym, jak i zakresu obowiązków.

Antropologiczny charakter wywiadów opartych na interakcjonizmie wymagał od badacza przygotowania, umiejętności zadawania pytań, wnikliwego słuchania oraz bycia aktywnym partnerem rozmowy. $Z$ uwagi na fakt, że praca traktuje o cieniach, a więc o zjawiskach niekoniecznie pozytywnych, głównym wyzwaniem podczas rozmów było zbudowanie zaufania i stworzenie naturalnej, koleżeńskiej atmosfery. Jest to także istotne z punktu widzenia samej metody i ograniczeń za nią idących, do których można zaliczyć ryzyko subiektywnych odczuć autentyczności, a także niebezpieczeństwo nieporozumień wynikających z różnic językowych, stres 
czy skrępowanie. Choć na etapie realizacji badań, a także ich późniejszej analizy, dołożono wszelkich starań, aby uzyskać jak najbardziej obiektywne rezultaty, to nie można założyć, że wypowiedzi rozmówców zawsze były szczere i pozbawione zbytniego uogólniania czy czysto subiektywnych odczuć, często zmieniających się na przestrzeni czasu. Sama świadomość uczestnictwa w badaniu mogła powodować także uczucie niepokoju, uruchamiać pewne mechanizmy obronne, a także sprawiać, że rozmówcy próbowali odpowiadać na pytania w taki sposób, jaki wydawał im się poprawny, a niekoniecznie taki, jaki jest zgodny z rzeczywistością.

By jak najbardziej ograniczyć powyższe negatywne aspekty związane z przeprowadzaniem wywiadów antropologicznych, kluczową wartością podczas rozmów była ich swobodność, osiągana poprzez zapewnienie rozmówcom całkowitej ochrony tożsamości, zwracanie się do nich po imieniu, stosowanie potocznego języka oraz częste posługiwanie się ironią czy żartem, co dodatkowo skracało dystans. Istotne $\mathrm{w}$ tym procesie było także udzielanie przez badacza dogłębnych odpowiedzi na pytania rozmówców, co było swoistą demonstracją partnerskiego charakteru i zachęcało członków organizacji do równie angażującego odzewu. Wywiady dotyczyły pracy w instytucji medialnej w ogóle, a nie samego zjawiska cienia organizacyjnego - podejmowano wątki z pozoru nieistotne, takie jak: proces rekrutacji do radia, trudne początki, wyobrażenia na temat branży medialnej, elementy zaskoczenia, relacje z pracownikami czy szkolenia dla radiowców. Dzięki tak holistycznemu podejściu do tematu, a także umożliwieniu rozmówcom swobodnego wypowiadania się pomiędzy badaczem a pracownikami wytworzyła się więź pozwalająca na dostrzeżenie zjawisk występujących w organizacji oraz zrozumienie pewnych schematów postępowania. Co ważne, zadawane pytania były konstruowane tak, aby w żaden sposób nie sugerowały odpowiedzi ani nie narzucały światopoglądu badacza. Długość tak prowadzonych rozmów wynosiła łącznie średnio od półtorej do dwóch i pół godziny. Choć wywiady odbywały się w przestrzeni online, to dzięki formie wideokonferencji badacz i pracownik mogli obserwować na bieżąco wzajemne reakcje. Bezpośrednio po każdym wywiadzie następowała jego dokładna transkrypcja, obejmująca całość rozmowy, a nie tylko wybrane wątki istotne z perspektywy badacza, co miało na celu wyeliminowanie błędu, jakim jest wybiórcza analiza.

Jako że zjawisko cienia organizacyjnego jest trudnym tematem nie tylko dla samej organizacji, ale przede wszystkim dla jej przywiązanych do miejsca pracy członków, podjęto decyzję o anonimizacji rozgłośni oraz posłużeniu się techniką nazwaną w artykule pseudonimizacją. Organizacja medialna określana jest jako Radio Nikotyna, a poszczególni pracownicy oznaczeni są odpowiednio: Jędrzej pracownik-wolontariusz, Stanisław - pracownik-wolontariusz, Zosia - pracowniczka-wolontariuszka, Wiktoria - prezenterka, Sara - prezenterka, Mikołaj - wydawca programowo-muzyczny oraz Aleksander - redaktor serwisów internetowych.

W toku analizy przeprowadzonych badań okazało się, że w badanej instytucji medialnej można wyróżnić trzy główne cienie organizacyjne, z których to każdy 
wiąże się z konkretnym etapem rozwoju pracownika. Aby jak najbardziej klarownie zaprezentować wyniki badań, posłużono się procesualnym opisem, ukazując drogę, jaką przechodzi statystyczny pracownik Radia Nikotyna od początku kariery do osiągnięcia dojrzałości zawodowej, a następnie wskazano na główną przyczynę rozwoju i istnienia cienia organizacyjnego.

\section{Pracownik-wolontariusz w cieniu organizacji}

Wiek XXI określany jest przez naukowców jako „cywilizacja medialna” (Goban-Klas 2005, s. 10). Żyjemy w świecie, którego fundamentem jest społeczeństwo informacyjne, a otaczające nas przekazy medialne są wszechobecne. W dobie konwergencji i upowszechnienia się środków masowego przekazu media tylko umocniły swoją pozycję, przez co coraz więcej młodych ludzi właśnie z nimi wiąże swoją przyszłość. Rozpoczęcie działalności w branży medialnej stanowi wyzwanie; standardy stale rosną, entuzjastów tego zawodu nie brakuje, a konkurencja jest ogromna. To właśnie dlatego studenci dziennikarstwa już podczas studiów szukają sposobu na zdobywanie doświadczenia, chcąc od najmłodszych lat szlifować swoje umiejętności praktyczne, niezbędne w pracy radiowca. Instytucje medialne odpowiadają na tę potrzebę, organizując specjalne oferty wolontariatu, praktyk i staży, współpracując z uczelniami, a także kreując własne organizacje studenckie. W podobny sposób działa Radio Nikotyna.

Propozycja rozgłośni polega na możliwości odbycia wolontariatu w strukturach radia, poznania jego funkcjonowania od wewnątrz, a także szkolenia się pod opieką najbardziej rozpoznawalnych głosów w Polsce. Choć taki wolontariat jest oczywiście bezpłatną formą, to aby otrzymać możliwość jego odbycia, trzeba przejść rekrutację, opierającą się na nagrywaniu tak zwanych demówek, ocenianych przez zarząd komórki zajmującej się studentami. Osoby aplikujące na takie stanowisko cechuje zapał do pracy i chęć umożliwienia sobie zatrudnienia w Radiu Nikotyna w przyszłości:

Sam fakt, że jestem w budynku jednej z większych rozgłośni radiowych w Polsce sprawia, że czuję się poważniej. Uwielbiam tworzenie programów radiowych. Chcę się uczyć i robię to. Widzę, jak potrafię się rozwinąć pod względem stylistycznym, lingwistycznym, technicznym. Dokształcam swoje umiejętności miękkie. Chcę wyszkolić się na tyle, aby spróbować przejść na etat w Radiu Nikotyna (Zosia).

I rzeczywiście. W opisie oferty dla studentów Radia Nikotyna znajduje się szereg zapewnień o zdobywaniu doświadczenia ułatwiającego wkroczenie na ścieżkę kariery zawodowej. Jednak deklarowane wartości nie są zbieżne z tymi przestrzeganymi, co prowadzi do powstania zjawiska cienia organizacyjnego już na etapie starania się o pracę w badanej rozgłośni. Cień ten generowany jest poprzez nierówne traktowanie 
pracowników-wolontariuszy, którzy są przekonani, że ich wysiłek nie jest oceniany w taki sposób, w jaki być powinien. Podstawowym elementem wpływającym na jego rozwój jest niejasność w kontekście przydzielania miejsc pracy:

To by było piękne i cenne, gdyby istniały wytyczne, kto i dlaczego może przeskoczyć. Wcześniej to było trochę na zasadzie doświadczenia, ale ostatnio umowę dostała osoba, która jest dużo krócej od innych. W czym ona jest lepsza, że zasłużyła na to stanowisko? Tego nie wie nikt (Jędrzej).

Często osoby, które są na umowie nie mają motywacji. Poziom się obniża, ten merytoryczny, artystyczny i warsztatowy. Ale nie ma możliwości zmienienia tej osoby bo nie wiemy, jak do tego dojść. Gdybym się zapytała, to pewnie by mi powiedziano, jak to zrobić, tylko byłoby to kosztem kogoś innego (Zosia).

Ta niepewność oraz sprzeczność z wartościami deklarowanymi sprawia, że studenci nie tylko tracą motywację do rozwoju i tworzenia coraz lepszych programów, ale także czują się mniej pewni siebie oraz sfrustrowani, co jest o tyle trudne, że przecież nie dostają żadnego finansowego wynagrodzenia za swoją pracę, a więc satysfakcja to jedyna forma zapłaty, na jaką mogą liczyć.

Przytoczone powyżej wypowiedzi odnoszą się do kolejnego przejawu omawianego cienia, a mianowicie braku wartościowych relacji w miejscu pracy. Stosunki pomiędzy poszczególnymi osobami, udzielającymi się na zasadzie wolontariatu, są powierzchowne, a uczestnicy organizacji otwarcie przyznają, że nie mogą sobie wzajemnie ufać. Relacje te cechuje rywalizacja, wzajemne ocenianie się, pozorna szczerość oraz szeroko pojęty brak wsparcia, także w walce o realizację wspólnych celów. W organizacji można zaobserwować wewnętrzne przyzwolenie na istnienie grup uprzywilejowanych, które umniejszają zasługi pozostałych i krytykują ich warsztat.

Jestem pewien, że w walce o etat wszystkie chwyty są dozwolone, szczególnie w mediach, gdzie ludzie są bardzo zafiksowani na swoim sukcesie. Widzę, że w naszej grupie też jest wiele osób, które budują swoją pozycję nie na tym, że pracują nad swoim warsztatem, tylko raczej osiągają cele, wytykając błędy innym i podkładając im nogę (Jędrzej).

Ogólnie czuję się już o wiele lepiej niż na początku, ale wiem, że tam aż roi się od plotek i komentarzy. Wiem, że część osób ma konwersacje w mediach społecznościowych poświęcone konkretnym prowadzącym, wycinają ich wejścia i śmieją się z nich. To jest bardzo przykre i powoduje, że kompletnie ci się odechciewa (Staszek).

Toksyczne relacje prowadzą do występowania zjawiska określanego jako „samotność w tłumie" (Riesman 2011). Brak zaufania w stosunku do współpracowników sprawia, że członkowie organizacji zupełnie zaprzestają kontaktów z innymi bądź ograniczają je do minimum. Jeśli już tworzą jakieś relacje, to raczej ze słuchaczami, 
jednak one nigdy nie mają charakteru bezpośredniego: „ja się raczej zamykam i przez te cztery godziny siedzę sam i mój kontakt to kontakt z ludźmi, którzy są po drugiej stronie mikrofonu, a nie po drugiej stronie drzwi” (Jędrzej). To szczególnie niebezpieczny skutek opisywanego cienia, przejawiający się w złym samopoczuciu, braku pewności siebie, niezadowoleniu z wykonywanej pracy i nieufności. Jak zaznacza Teresa Chirkowska-Smolak (2009, s. 263), złe relacje interpersonalne są także jedną z pięciu przyczyn wypalenia zawodowego.

Celowo i z premedytacją w powyższym rozdziale stosowano głównie terminy: „praca” oraz „pracownik-wolontariusz” zamiast określeń typu: „wolontariat”, „staż” czy „praktyki”. Wiąże się to z faktem, że pomimo braku finansowego wynagrodzenia studenci poświęcają organizacji większość swojego wolnego czasu, angażując się w jak najlepsze wykonywanie powierzonych im obowiązków. Często po przeliczeniu godzin spędzonych w radiowej przestrzeni okazuje się, że czas ten odpowiada nawet $3 / 4$ normalnego etatu. Co istotne, Radio Nikotyna jest jedną z największych komercyjnych rozgłośni radiowych w Polsce, a więc jego budżet opiera się głównie na wpływach z zewnętrznych reklam. W związku z tym niejednokrotnie zdarza się, że studenci zobligowani są do aktywnego tworzenia płatnych kampanii reklamowych, co potęguje w nich poczucie niesprawiedliwości:

Boli. Bardzo boli. To jest temat, z którym długo się borykam i długo walczę, bo odczuwam, że jest to grubo niesprawiedliwe. To wszystko, co my umiemy, umiemy z własnego doświadczenia. Te pieniądze z reklam, którymi akurat my się zajmujemy, nie idą na rozwój. To też powód, przez który miałam wątpliwość, czy zostać w radiu (Zosia).

Powyższa wypowiedź zdradza kolejny negatywny skutek spychania pracowników-wolontariuszy do cienia. Osoby korzystające z oferty dla studentów pracują za darmo pod pretekstem nauki i zdobywania doświadczenia, a w rzeczywistości wszystkich rzeczy uczą się same. Oczywiście, doświadczenie zdobywa się, praktykując, jednak będąc na stażu, oczekuje się pewnego rodzaju wskazówek, szkoleń czy zbiorowych ćwiczeń. Tutaj tego nie ma. Element wspólnej pracy nad warsztatem pojawia się jedynie na samym początku, w okresie tworzenia wcześniej wspomnianych „demówek”, kiedy to redaktor naczelny wraz z prowadzącym odsłuchuje i analizuje program. Później już nic takiego nie występuje: „Ta praca nad warsztatem leży bardziej po Twojej stronie - sam musisz siebie kontrolować, sam umawiać się na odsłuchy, bo tak cyklicznie nie ma czegoś takiego" (Jędrzej). Taki stan rzeczy sprawia, że nasuwa się pytanie o to, czy aby na pewno oferta dla studentów ma im pomóc wejść $\mathrm{w}$ medialny świat, czy jest tylko sposobem na pozyskanie darmowych pracowników, którzy dążąc do zatrudnienia, będą prezentować najwyższą jakość, niezależnie od warunków współpracy. Podobne rozważania podejmowała Pamela Ślufińska (2014, s. 195-220), opisując sytuacje, w których wolontariat staje się układem pełnym nieprawdziwych obietnic awansu, regularnego łamania zasad 
oraz organizacyjnego bałaganu. Warto także zaznaczyć, że tego typu praktyki nie są domeną jedynie polskich organizacji medialnych. To sposób wykorzystywany przez firmy na całym świecie, które chcąc ograniczyć wydatki, rekrutują bezpłatnych stażystów, oferując w zamian możliwość wkroczenia na ścieżkę kariery. Obszar ten od lat jest zajmującym przedmiotem badań i analiz, o czym świadczy istnienie artykułów naukowych, takich jak chociażby All Work and No Pay: Consequences of Unpaid Work in the Creative Industries (Siebert, Wilson 2013), który pokazuje niebezpieczeństwa, jakie wiążą się z praktyką nieodpłatnej pracy, zarówno z perspektywy samych stażystów, jak i osób już zatrudnionych w danej firmie.

Opisane powyżej zjawiska są następstwami spychania w cień osób pracujących na zasadzie wolontariatu, co prowadzi do szeregu negatywnych skutków rzutujących na ich zawodową przyszłość. Młodzi entuzjaści dziennikarstwa, angażując się w pracę za darmo, narażeni są na nierówne traktowanie, toksyczne relacje oparte na rywalizacji, brak jakiekolwiek informacji zwrotnej dotyczącej jakości swojej pracy, a także niejasne kryteria zatrudnienia. Jest to o tyle paradoksalne, że powyższe konsekwencje cienia organizacyjnego teoretycznie powinny być formą pozamaterialnego wynagrodzenia za wolontaryjną pracę w studenckiej części Radia Nikotyna. Nasuwa się zatem pytanie: czy uczestnicy organizacji mają świadomość, że zostali zepchnięci do cienia? Jak pokazują badania, studenci w większości zdają sobie sprawę z sytuacji, w jakiej się znaleźli. Co prawda świadomość ta przychodzi z czasem, co widoczne jest w samych wypowiedziach pracowników-wolontariuszy, którzy początkowo nie wspominali o negatywnych aspektach, jakich doświadczają. O przejawach niesprawiedliwości opowiadali dopiero po kilkudziesięciu minutach rozmowy w formie wywiadu otwartego. Może to świadczyć o tym, że trudno im przyznać otwarcie, że trwają w miejscu, w którym nie są traktowani tak jak powinni i że świadomie się na to godzą. A godzą się, ponieważ traktują tę studencką przygodę z radiem w sposób przejściowy, mając nadzieję, że kiedy będą zatrudnieni, wszystko się zmieni. Ponadto choć są to osoby młode, to cechuje je pewna dojrzałość, pozwalająca na zdystansowanie się wobec negatywnych skutków bycia w cieniu i umiejętność realizacji swoich indywidualnych celów:

To na pewno przeszkadza, ale staram się tym nie przejmować, bo co mi to da? Miewałem już takie sytuacje, że wykonywałem swoją pracę na pół gwizdka z powodu braku motywacji. I bardzo tego nie chcę. Mam ograniczone zaufanie, robię najwięcej rzeczy sam, korzystam z kontaktu z osobami, na których wiem, że mogę polegać, próbuję korzystać z infrastruktury i dążyć do jakiegoś samorozwoju (Jędrzej). 


\section{Autorskośc „entuzjastycznych debiutantów” w cieniu organizacji}

Znaczna część nowych pracowników Radia Nikotyna nie pochodzi z zewnątrz - są to osoby korzystające wcześniej z oferty dla studentów, wychodzące z cienia, do którego zepchnięto je w czasie trwania wolontariatu. Możliwość zatrudnienia w wymarzonej organizacji stanowi dla nich najwyższą formę docenienia i zadośćuczynienia. Nierówne traktowanie, niespójne kryteria przyznawania etatów, a także relacje oparte na rywalizacji zastąpione zostają poczuciem ekscytacji, dumy i spełnienia. Opierając się na koncepcji przywództwa sytuacyjnego Paula Herseya i Kena Blancharda (1979, s. 6), moglibyśmy określić tę grupę mianem „entuzjastycznych debiutantów”, posiadających wysokie aspiracje i jednocześnie potrzebujących wsparcia oraz odpowiedniego wprowadzenia w zawód. Praca w mediach jawi im się jako taka, w której będą mogli wykorzystać swój potencjał oraz zaimponować pomysłowością i tworzeniem ambitnych, nieszablonowych form o ponadprzeciętnej jakości. Dzieje się jednak zupełnie inaczej. Ten potencjał i zapał, stanowiące teoretycznie największe zalety młodego pokolenia radiowców, zostają zepchnięte do tak zwanego złotego cienia organizacji (Kostera 2010, s. 70). Idąc za Kosterą, mianem tym określamy cechy związane z wszelkimi przejawami społecznie nieakceptowanej twórczości.

Niezależnie od tego, czy nowy pracownik Radia Nikotyna miał już wcześniej z nim styczność podczas wolontariatu, początki opierają się na ponownych nagraniach tak zwanych demówek, ocenianych przez szefostwo stacji. Wówczas następuje proces nazywany nieoficjalnie w rozgłośni „, formatowaniem nowego pracownika”, mający na celu wyuczenie nowo przybyłych pewnych uniwersalnych schematów działania. Jednolitość, podobne brzmienie, tendencyjna tematyka i brak wyraźnej charyzmy to główne wartości, jakie doceniane są w stacji Nikotyna, która praktycznie całkowicie zrezygnowała $\mathrm{z}$ audycji autorskich na rzecz formatowanych odgórnie pasm DJ-skich:

Ten czas demówek jest taki nerwowy. Nowi ludzie zanim zaczną być na antenie, to muszą nagrać kilkanaście takich dem. To jest szlifowanie i głosu, i tych umiejętności emisyjnych, ale także szlifowanie pod kątem merytorycznym i programowym, jesteś formatowana pod kątem słuchacza tego konkretnego radia (Sara).

Zostałam przybita do ściany, bo są tam straszne obostrzenia odnośnie nowo przybyłych (...). Dostałam proste polecenie: „masz być słodka, kokietująca i trochę głupiutka” (Wiktoria).

Przez lata istnienia na rynku rozgłośnia wypracowała wzorce działania, których rygorystycznie przestrzega. Zmiany wprowadzane są powoli i stopniowo, głównie w okresach letnich, kiedy to słuchalność jest niższa z uwagi na mniej uporządkowany tryb życia odbiorców. Taki sposób zarządzania związany jest z pewnością z komercyjnym charakterem radia, które Robert Picard (1989, s. 17) określiłby jako „produkt podwójnego rynku". Podobne postrzeganie można spotkać u Beliczyńskiego 
podkreślającego, że radio komercyjne obecne jest na rynku odbiorców oraz reklamodawców (Beliczyński 2015, s. 88-89), przez co wyróżnić można dwa obszary działalności takiej stacji. Pierwszy dotyczy audycji samej w sobie i oparty jest na wymianie relacji pomiędzy prezenterem a słuchaczem. Drugi natomiast wiąże się z udostępnianiem reklamodawcom publiczności, która w pewnym stopniu stanowi ich grupę docelową. Wyznacznikiem komercyjnych stacji radiowych jest sposób finansowania. Według Stanisława Jędrzejowskiego (2003, s. 89-90) aż około 80-85\% przychodów takich instytucji medialnych stanowią dochody z reklam. Z pewnością jest to główny powód, dla którego słuchacze są nadrzędnym wyznacznikiem działalności Radia Nikotyna, i to oni, a nie pracownicy radia, mają największy wpływ na treści, jakie ono oferuje. Jak podkreśla Magdalena Steciąg (2006, s. 17), „radio komercyjne nie nadaje żadnych audycji misyjnych i nie posiada żadnego obowiązku społecznego - działa, aby zdobyć jak najszerszą publiczność". Powyższa definicja idealnie zdaje się określać Radio Nikotyna, którego celem nie jest uprawianie dziennikarstwa jakościowego, a rosnący procent udziału w rynku medialnym: „chodzi o słuchalność, bo to się przekłada na reklamodawców - im więcej reklamodawców, tym większe pieniądze, a im więcej pieniędzy, tym oczywiście lepiej” - argumentuje Mikołaj, dodając, że autorskość jest domeną mniejszych stacji radiowych, głównie tych publicznych.

Radio Nikotyna swoim uniwersalnym charakterem przyciąga słuchaczy, a później, bazując na mechanizmach przyzwyczajenia, coraz bardziej ich „lojalizuje”. Grupę docelową rozgłośni cechuje spora różnorodność, będąca wynikiem ogromnej popularności stacji w Polsce. Jak podkreślają pracownicy, praktycznie każda osoba zapytana o Radio Nikotynę, niezależnie od wieku, zawodu, upodobań politycznych czy zainteresowań, będzie w stanie skojarzyć organizację. Ta heterogeniczność grupy docelowej jest jednym z powodów, dla którego potencjał pracowników i potrzeba tworzenia ambitnych treści spychana jest do cienia.

Trzeba nabrać do tego dystansu (...). Komunikat ma być jednocześnie zrozumiały dla siedmioletniego dziecka, rolnika słuchającego radia w traktorze, kelnerki w restauracji, zabieganej mamy robiącej zakupy, aktywistki walczącej o ekologię, przeciwnika małżeństw homoseksualnych, kierownika w jakiejś firmie i prezesa wielkiej spółki. Mówiąc najprościej - każdy musi cię zrozumieć, a nikt nie poczuć się urażony. To jest ta nasza radiowa sztuka (Wiktoria).

Dualizm rynków, na których działa radio komercyjne, przejawia się nie tylko w dążeniu do uniwersalizmu pod kątem treści. Obecność na rynku reklamodawców i związane z nią komercjalizowanie czasu antenowego także w sporym stopniu rzutują na pracę dziennikarza Radia Nikotyna, jako że jest on zobligowany do przekazywania informacji na temat towarów bądź usług, z którymi niekoniecznie się zgadza bądź które nie pasują do tematyki jego programu. Częstym zjawiskiem jest także przerywanie wejść antenowych w celu wyemitowania konkretnej reklamy. Wiąże się z tym 
nie tylko pewnego rodzaju irytacja, ale także ogromna odpowiedzialność, ponieważ umowy reklamowe są pełne obostrzeń i wymagań dotyczących prezentacji danego produktu. Zniechęcające dla młodych dziennikarzy bywa także przeprowadzanie loterii i wszelkiego rodzaju konkursów mających na celu pozyskanie dodatkowego źródła dochodu. Tego rodzaju akcje zajmują bardzo dużo czasu i uniemożliwiają prowadzenie swobodnych programów o pewnej ciągłości i strukturze. Ten obszar cienia organizacyjnego $\mathrm{w}$ najgorszym przypadku kończy się całkowitą rezygnacją z pracy antenowej: „ludzie, niezależnie od stażu pracy, mogą się zmęczyć tym ciągłym mówieniem o SMS-ach, o loterii oraz tym, że to jest schemat, że nie można zrobić sobie nic swojego" (Sara). Ten szeroko omawiany brak autorskości przejawia się nie tylko w doborze tematyki programów i sposobach ich prezentacji - pracownicy Radia Nikotyna nie mają żadnego wpływu na muzykę pojawiającą się podczas ich programów, nie mogą samodzielnie decydować o doborze gatunku, nie wspominając o konkretnej playliście.

Wobec przytoczonych zjawisk członkowie rozgłośni przyjmują postawę uległości, a wcześniejszy zapał zastępuje przyzwyczajenie do wyuczonych schematów i przekonanie, że to nie jakość materiałów, a liczba słuchaczy jest wyznacznikiem ich wartości. Bierność w walce o autorski charakter audycji wynika także z faktu, że decydując się na pracę pod szyldem Radia Nikotyna, pracownicy zrzekają się wszystkich praw do materiałów, jakie stworzą w okresie obowiązywania umowy, co z pewnością odbiera im motywację do prób kreowania nowych form i idącego za tym rozwoju osobistego: „Podstawą jest to, że wszystkich praw w umowie się wyzbywamy, wszystko, co robimy w pracy, jest Nikotyny, a nie jest nasze" (Sara).

Powyżej opisany złoty cień organizacyjny, tworzący się wskutek dążenia do możliwie jak najbardziej spektakularnego sukcesu komercyjnego, jest jednym z najsmutniejszych elementów pracy w Radiu Nikotyna. Cień zazwyczaj kojarzy się z przestrzenią, do której trafiają negatywne zjawiska, mające miejsce $\mathrm{w}$ danej organizacji. Tu mamy sytuację odwrotną - do cienia przedostają się pozytywne cechy entuzjastycznie nastawionych adeptów dziennikarstwa. Jak każdy cień, także i ten rodzi szereg negatywnych skutków. Do najważniejszych można zaliczyć brak motywacji do samorozwoju wśród pracowników organizacji, a także rezygnację z krytycznego myślenia oraz zastępowanie swoich indywidualnych cech cechami społecznie akceptowanymi, pozbawionymi osobowości i wyrazu. Skutki tak rozumianego cienia widoczne są nie tylko w zmianie myślenia pracowników. Od strony formalnej ich naoczną egzemplifikacją jest chociażby fluktuacja kadr i migracje, widoczne zwłaszcza wśród młodego pokolenia, które często nie radzi sobie z tak dużymi obostrzeniami oraz nadmierną kontrolą, uniemożliwiającą swobodę wypowiedzi: „Po drugiej stronie często siedzi szef anteny, więc jak powiesz coś nie tak, to on wstaje i dostajesz takie piorunujące spojrzenie, dlatego mówię, że ta wolność słowa jest bardzo moderowana" (Wiktoria). To grupowe tworzenie programów zgodne z ustalonym schematem sprawia także, że zanika poczucie odpowiedzialności za 
słowa wypowiadane na antenie, co jawi się jako szczególnie niebezpieczne, biorąc pod uwagę słuchalność stacji. I tu pojawia się pytanie o status dziennikarza w mediach komercyjnych. Zatrudnienie w Radiu Nikotyna jest pożądane wśród studentów dziennikarstwa, którzy chcą rozwijać się w zawodzie i trafiać do dużej grupy ludzi. Okazuje się jednak, że porzucenie misji społecznej i skupienie wyłącznie na komercyjnych celach sprawia, że obecnie zatraca się sens dziennikarstwa a jego miejsce zajmuje „zawód medialny”, co omawiał szeroko Ryszard Kapuściński, a później na gruncie nauk o zarządzaniu - Bogusław Nierenberg (2011, s. 169). Członkowie Radia Nikotyna z dziennikarzy przekształcają się w „pracowników mediów”, a ich początkowe cele i aspiracje zupełnie zanikają. Powracając do koncepcji przywództwa sytuacyjnego Herseya i Blancharda, można powiedzieć, że pracownicy organizacji przechodzą do etapu, który określa się mianem „wątpiących praktyków”.

\section{Nieadekwatna polityka wynag̉rodzeń cieniem org̉anizacji}

Kariery w Radiu Nikotyna zaczynają się stosunkowo wcześnie i trwają z zasady długo. Młody człowiek, wchodząc w struktury rozgłośni, rozpoczyna od poziomu pracownika-wolontariusza. Wybrani studenci, po przejściu procesu „formatowania”, stają się pełnoprawnymi członkami organizacji. Choć cień organizacyjny widoczny jest na każdym etapie rozwoju, są pracownicy, którzy nie chcą rezygnować z pracy w jednej z największych komercyjnych rozgłośni w Polsce i stopniowo przestają dostrzegać negatywne cechy, spychając je do nieświadomości. Długoletni pracownicy stacji to osoby mające doświadczenie niemal na każdym stanowisku - od asystenta, przez wydawcę, twórcę playlist, redaktora serwisów internetowych po prezentera. Wydawać by się mogło, że długi staż pracy, cenne doświadczenie, lojalność wobec marki, a także zatrudnienie w jednej z największych i najpopularniejszych rozgłośni radiowych w Polsce gwarantuje im ponadprzeciętne wynagrodzenia finansowe, adekwatne do umiejętności i pracy włożonej w rozwój zawodowy. Jak pokazują badania, rzeczywistość jest zupełnie inna:

To nie jest najwyższy pułap, jeśli chodzi o zarobki. Źle robi opinia ludzi mówiąca, że jak jesteś w Radiu Nikotyna, to nie wiadomo ile zarabiasz, nie jest tak. Mniemanie ludzi o tym, że zarabia się dużo, jest mylne, bo nie są to druzgocące pieniądze. Ja uważam, że wypłata jest całkiem okej, ale na pewno nie jest adekwatna (Aleksander).

Zarobki w Radiu Nikotyna są jednym z najbardziej zacienionych obszarów organizacji. Jest to kwestia spychana do cienia przez pracodawców, którzy nie mają potrzeby adekwatnego wynagradzania członków organizacji, ale także przez samych członków, którzy pomimo zdawania sobie sprawy z zaniżonych stawek usiłują usprawiedliwiać ten fakt: 
Raczej nigdy nie pojawia się temat pieniędzy. Nie sądzę, żeby pieniądze były najważniejsze bardziej ten fun i zabawa. Pieniądze są na bocznym torze, liczy się to, żeby zrobić coś, co spodoba się innym i też nam. Coś, co będzie na dużą skalę (Mikołaj).

Ten „fun i zabawa" stanowią najważniejszą formę wynagrodzenia dla pracowników Radia Nikotyna, zwłaszcza na początku kariery zawodowej. W Zarządzaniu personelem Kostera (2000) wyróżniła płacę, wynagrodzenia niematerialne, możliwość zrobienia kariery zawodowej oraz poczucie misji jako główne typy gratyfikacji uczestników organizacji. Płaca jest najbardziej podstawową formą, której wysokość zależy od przyjętego w organizacji wartościowania stanowisk. System wynagradzania praktykowany w Radiu Nikotyna zdaje się w najmniejszym stopniu opierać na gratyfikacjach materialnych, a bazuje głównie na poczuciu satysfakcji pracowników, związanym z rangą i marką rozgłośni. Oczywiście błędne byłoby stwierdzenie, że zarobki pracowników są niewystarczające. Chodzi tu bardziej o ich adekwatność do wysiłku i zaangażowania wkładanego w pracę, a także ich współmierność w stosunku do stawek rynkowych. Odwołując się ponownie do Kostery (2000, s. 105), Radio Nikotynę można zaliczyć do organizacji stosującej taktykę „ogona płacowego" bądź - w przypadku niektórych stanowisk - „solidnego środka”. Choć pracownicy zdają się mieć w pewnym stopniu świadomość sytuacji, to wynagrodzenia pozamaterialne związane z przekonaniem, że za dużą marką stoi najwyższy poziom profesjonalizmu, sprawiają, że problem finansowej gratyfikacji spychany jest przez nich do cienia. Wykorzystanie takich taktyk w Radiu Nikotyna wydaje się niespodziewane, biorąc pod uwagę fakt, że jest to rozgłośnia będąca jednym z liderów branży medialnej, posiadająca stabilną sytuację na rynku reklamodawców, zapewniającą płynność finansową. Niektórzy zatrudnieni w Radiu Nikotyna po cichu mówią, że „wszystko, co dzieje się na zewnątrz, jest z rozmachem, bo nie oszczędza się na niczym, tylko na pracownikach, wymagając najwyższych standardów za najniższe stawki” (Aleksander).

Pracownicy organizacji zgodnie z wymaganiami zarządu powinni cechować się wysokim zaangażowaniem, bezgraniczną lojalnością w stosunku do marki, a także pełną dyspozycyjnością. Zatrudnienie w Radiu Nikotyna wiąże się z nienormowanym czasem pracy, wynikającym $z$ informacyjnej funkcji radia i konieczności bieżącego reagowania na to, co dzieje się w kraju i na świecie. Polityka wynagrodzeń przewiduje jednak płacę stałą, odpowiadającą warunkom umowy. Oznacza to, że jeśli pracownik został zatrudniony na pełen etat, to niezależnie od tego, ile praca realnie zajmuje, otrzyma on jednakowe wynagrodzenie. Oczywiście nie każdy dzień generuje dodatkowe obowiązki, jednak z doświadczenia członków organizacji wynika, że znacznie częściej czas pracy się wydłuża, aniżeli skraca. Pracownicy mimo wszystko kierują się sumiennością w wypełnianiu zadań, działając w myśl zasady, że „radio musi grać” (Sara), stanowiącej dla nich większą wartość niż wynagrodzenie, które nie uwzględnia tej nieprzewidywalności godzin pracy. 
Szczególnie ciekawym zjawiskiem w kontekście cienia organizacyjnego, jakim jest nieadekwatne wynagradzanie pracowników, jest sam proces jego tworzenia. Jawi się to jako interesujące, zwłaszcza biorąc pod uwagę, że teoretycznie pracownicy zdają sobie sprawę, że w mniejszych rozgłośniach, w których ich zakres obowiązków byłby znacznie węższy, mogliby otrzymać porównywalne, a częściej wyższe wynagrodzenie. Dlaczego więc spychają tę kwestię do nieświadomości, rezygnując z prób walki o sprawiedliwą płacę? Otóź, jak pokazują przeprowadzone badania, sama wiedza na temat rynkowych stawek nie oznacza pełnej świadomości własnego położenia, co jest wynikiem starannie wypracowanego schematu zarządzania Radiem Nikotyna.

Otrzymanie zatrudnienia w tak dużej stacji komercyjnej jest wyzwaniem. Od kandydatów wymaga się umiejętności i doświadczenia niezależnie od wieku, dlatego znaczna część studentów już na wczesnym etapie kształcenia decyduje się na różnego rodzaju praktyki i staże oferowane przez Radio Nikotyna. Zgodnie z narracją organizacji brak wynagrodzenia pracowników-wolontariuszy usprawiedliwia brak doświadczenia wynikający z młodego wieku. Studenci zgadzają się na taki układ, wierząc, że to ułatwi im start w karierze. I rzeczywiście, w niektórych przypadkach tak jest. Radio Nikotyna stawia na osoby młode, których pozycja i rozpoznawalność kreuje się dopiero podczas pracy w rozgłośni. Kariery zaczynają się dość wcześnie, co ma swój ukryty sens:

Zatrudnia się młodych ludzi, których można wyszkolić po swojemu, bo wtedy można zapłacić im mało i nie wydaje się to dziwne. To jest na tyle duża firma, że zawsze przyjdzie ktoś nowy, kto chętnie się czegoś nowego nauczy, będzie robił to z tym swoim młodzieńczym zapałem i równie dobrze, ale za mniejsze pieniądze (Wiktoria).

Młodzi ludzie na początku medialnej drogi nie mają dużych oczekiwań finansowych, co wynika $\mathrm{z}$ braku znajomości rynku pracy. Utarty stereotyp głoszący, że „po dziennikarstwie nie ma pracy w zawodzie”, tylko umacnia ich postawę uległości w stosunku do proponowanych płac: „cieszę się, że mogę robić to, co jakoś mnie interesuje i że w ogóle ktoś chce mi za to płacić" (Mikołaj). Studenci, często podatni na manipulację, zorientowani na celu, jakim jest praca w popularnej rozgłośni, angażujący się wcześniej za darmo, nie kierują się pobudkami finansowymi, co jest konsekwentnie wykorzystywane przez stację, która na start proponuje najniższe z możliwych stawek. Im dłuższy staż, tym wynagrodzenie jest nieznacznie podwyższane, co sprawia, że pracownicy zyskują dodatkową motywację, wynikającą z przekonania, że lojalność i zaangażowanie procentuje:

Im się jest wierniejszym, tym lepiej. Początki są trudne i jeśli wtedy się zniechęcisz, no to sorry. Nikotyna znajdzie kogoś lepszego i tańszego na twoje miejsce. Ludzie pracujący wiele lat mają znacznie lepiej (Mikołaj). 
Zwiększanie pensji jest raczej standardowym zabiegiem, jak najbardziej zgodnym ze znanymi mechanizmami wynagradzania pracowników. W tym przypadku problem polega na tym, że startując od najniższego pułapu i zwiększając go nieznacznie okresowo, nigdy nie dochodzi się do stawek adekwatnych dla tego typu pracy. Członkowie organizacji są zadowoleni, ponieważ każdą podwyżkę, nawet tę minimalną, traktują jako docenienie i dobry znak na przyszłość, ufając bezgranicznie marce Radia Nikotyna. Często wynika to także z tego, że rozpoczynając pracę jako młodzi studenci i kontynuując ją przez kilka lat w tym samym miejscu, nie mają porównania z innymi stacjami; wiedzą, że stawki są zaniżone, często nawet dwukrotnie, jednak brak osobistego doświadczenia sprawia, że nie odczuwają tego w dobitny sposób.

Polityka wynagradzania pracowników i jej wpływ na motywację zajmuje badaczy właściwie od początku istnienia nauk o zarządzaniu. Taylor, uważany za ojca naukowego zarządzania, wskazywał pieniądze jako główny czynnik, dla którego ludzie w ogóle podejmują pracę. Szybko jednak okazało się, że gratyfikacja finansowa sama w sobie nie jest gwarantem najwyższej wydajności pracowników. Jak pokazały badania Mayo, na zadowolenie $\mathrm{z}$ wykonywanej pracy ma wpływ szereg innych czynników, do których zaliczyć możemy chociażby relacje ze współpracownikami czy satysfakcję wynikającą z udziału w tworzeniu finalnego produktu. Bazując na tych obserwacjach, Douglas McGregor (1960) wyróżnił dwie teorie opierające się na założeniach co do natury ludzkiej - teorię X, zakładającą, że człowiek jest leniwy z natury, nie lubi pracować i traktuje zatrudnienie jako konieczność wyższą, umożliwiającą mu przeżycie, oraz teorię Y, według której równie istotne co sens ekonomiczny są wartości, takie jak wykorzystanie własnego potencjału, satysfakcja i poczucie sensu. Przeprowadzone badania pokazują, że typowy pracownik Radia Nikotyna jest wręcz modelowym odzwierciedleniem teorii Y. Członkowie organizacji szukają w pracy głównie zrozumienia, relacji, możliwości wykazania się, uznania i samodzielności, stawiając wynagrodzenie na dalszym miejscu. Popularna piramida Maslowa, określająca hierarchię potrzeb ludzi z założeniem, że potrzeby wyższego rzędu nie mogą być realizowane bez zaspokojenia potrzeb niższego rzędu, zdaje się nie mieć zastosowania w tym przypadku. Bardziej odpowiednia jest teoria ERG, opracowana przez Claytona Alderfera (1972), zastępująca Maslowowską kolejność założeniem, że zaspokajanie potrzeb egzystencji, związku i wzrostu może dziać się równocześnie bądź nawet w kolejności odwróconej, co znakomicie obrazują postawy, zwłaszcza najmłodszych, pracowników Radia Nikotyna. To właśnie ten czynnik, leżący niejako w naturze i charakterze członków rozgłośni, sprawia, że kwestie niesprawiedliwego wynagradzania spychane są do nieświadomości, tworząc jeden z najbardziej zacienionych obszarów, który uwidacznia się i prowadzi do negatywnych skutków dopiero po kilku latach pracy, wraz z powolnym nabieraniem doświadczenia i dystansu do samej marki. Pracownicy Radia Nikotyna utożsamiają pracę z pasją, co sprawia, że niezależnie od gratyfikacji finansowej wykonują ją 
najlepiej jak się da. Nie potrafią i nie próbują walczyć o swoje prawa, a zarząd stacji zdaje się doskonale to wykorzystywać.

\section{Mit marki przyczyną rozwoju cieni organizacyjnych}

W Radiu Nikotyna można wyróżnić trzy podstawowe etapy rozwoju pracownika: pracownik-wolontariusz, pracownik początkujący oraz pracownik dojrzały. Każdej z tych faz towarzyszy cień powstały wskutek odrzucenia pewnych elementów w czasie tworzenia się tożsamości organizacyjnej. Do głównych cieni Radia Nikotyna można zaliczyć nierówne traktowanie pracowników-wolontariuszy, marnowanie potencjału początkujących radiowców, a także nieadekwatne wynagradzanie doświadczonych pracowników. Co ciekawe, każdy z tych etapów cechuje się odmiennym poziomem świadomości członków organizacji, co określić można jako „balansowanie na pograniczu świadomości i nieświadomości”. Teoretycznie wydawać by się mogło, że im pracownik jest dojrzalszy i im więcej czasu spędza w organizacji, tym więcej dostrzega. Zaskakującą różnicą jest jednak fakt, że ta świadomość jest niejako wtórna. Pierwsza jej faza pojawia się już na samym początku kariery w rozgłośni, a nawet przed jej oficjalnym rozpoczęciem. Student, który odbywał wolontariat w rozgłośni, decydując się na podjęcie zatrudnienia, doskonale zdaje sobie sprawę ze wszystkich opisanych przejawów cienia organizacyjnego, jednak mimo wszystko decyduje się na kontynuowanie ścieżki zawodowej właśnie w tej konkretnej instytucji. Źródło takiego stanu rzeczy może tłumaczyć pojęcie identyfikacji pracownika z miejscem pracy, wynikającej z istnienia mitu marki będącego podstawowym elementem wewnętrznej tożsamości organizacji. Jak wielokrotnie podkreślano w niniejszym artykule, Radio Nikotyna to jedna z największych i najpopularniejszych rozgłośni radiowych w Polsce, a jej silna marka to efekt wieloletniego istnienia na rynku. I to właśnie ta marka, będąca wartością symboliczną, jest równocześnie przyczyną powstawania wszelkich cieni organizacyjnych, a także przyzwoleniem na ich rozwój. Naomi Klein (2009) w pozycji No Logo opisuje negatywne skutki kreowania idealnego wizerunku marki na zewnątrz, wskazując na niespójność wartości deklarowanych i przestrzeganych, co przyczynia się w konsekwencji do poczucia niesprawiedliwości i frustracji wśród pracowników. W Radiu Nikotyna występuje podobne zjawisko z tą różnicą, że odnosi się do budowania wewnętrznej tożsamości.

Radio Nikotyna, kreując swoją markę, skupia się nie tylko na wizerunku zewnętrznym, ale przede wszystkim na wewnętrznym, budując wśród pracowników poczucie prestiżu, przywiązania i przekonania, że praca w tak dużej rozgłośni już sama w sobie jest nagrodą i wystarczającym docenieniem:

Jest tu takie podejście, że to radio powinno być twoim życiem, a nie pracą. Powinieneś się cieszyć, że jesteś częścią projektu, jakim jest Radio Nikotyna, i to powinno cię napawać, a nie 
jakieś pobudki finansowe. Każdy chce tu być i pracować tutaj, więc można płacić mniej pracownikom (Mikołaj).

Ten symboliczny wymiar rozgłośni staje się tak silnym bodźcem, że radiowcy spychają w cień wszelkie niedogodności. W wypowiedziach bardziej świadomych pracowników pojawia się nawet określenie „religia Radia Nikotyna”, wskazujące na skalę przywiązania uczestników do organizacji. W tej rozgłośni się nie pracuje, tę rozgłośnię po prostu się wyznaje. Największą wartością jest tu możliwość określania siebie jako pracownika Radia Nikotyna, co jest wynikiem silnej identyfikacji członków z marką. Samo pojęcie identyfikacji pracownika z firmą na gruncie nauk o zarządzaniu rozumie się jako:

Stan, w którym pracownik w pełni akceptuje kulturę organizacyjną, klimat i politykę firmy, jej strategię i cele, wykorzystywane w firmie procedury, a także cel własnego stanowiska pracy oraz jego miejsce i wagę w strukturze organizacji. Identyfikacja sprawia, że pracownik czuje się częścią firmy, w której pracuje, dlatego poświęca się jej i jest w stosunku do niej lojalny (Aleksander 2008, s. 142).

I to właśnie ta definicja zdaje się idealnie opisywać pracowników Radia Nikotyna, którzy wyzbywają się swoich początkowych wartości i wyobrażeń na temat pracy radiowca, stając się oddanymi media-workers.

Zdaniem Davide’a Ravasiego i Majken Schulz (2006, s. 437) do poczucia identyfikacji z marką przyczynia się kultura organizacyjna, do której zalicza się wspólne wierzenia, rytuały oraz artefakty kulturowe. W Radiu Nikotyna podstawą tejże kultury jest wiara w siłę marki rozgłośni i przekonanie o tym, że jest najlepszym z możliwych miejsc pracy. Nie bez znaczenia pozostają także relacje z pracownikami, które z czasem przestają się opierać na rywalizacji, a przybierają partnerski charakter, co wynika z otrzymania zatrudnienia oraz idącego za nim poczucia bezpieczeństwa i pewności siebie. Wysoko cenione są także rytuały, do których zaliczyć można wspólne picie kawy i jedzenie obiadu o określonych godzinach, wyjścia na spotkania integracyjne czy konkretne, charakterystyczne dla rozgłośni powiedzenia.

Próby zepchnięcia przejawów cieni organizacyjnych do sfery nieświadomości wynikają także z wewnętrznego przekonania, że odchodząc z rozgłośni i próbując swoich sił w innej stacji radiowej, nie ma się już możliwości powrotu. Opuszczając szeregi Radia Nikotyna, przechodzi się automatycznie z pozycji „przyjaciela” do statusu „zdrajcy”, co udowadnia, że relacje - choć określane przez pracowników jako motywujące i wartościowe - są w gruncie rzeczy pozorne. Identyfikacja $\mathrm{z}$ marką $\mathrm{w}$ tym przypadku jest więc wynikiem nie tylko pozytywnych przejawów kultury organizacyjnej, ale także powszechnej negatywnej narracji odnoszącej się do innych stacji i wszelkich podmiotów na zewnątrz organizacji, co widoczne jest w samej warstwie językowej pracowników, którzy mówiąc o nawykach, zwyczajach 
i warsztacie członków pozostałych komercyjnych instytucji medialnych, w tym byłych współpracowników, używają określenia „zły”, zamiast „inny”. Wszechobecna krytyka, uniemożliwiająca ponowne zatrudnienie w rozgłośni w przyszłości, sprawia, że pracownicy boją się odchodzić lub otwarcie mówić o cieniach organizacyjnych, które zauważają:

Takie sprawy są tuszowane. Bo nie można tej magii i religii Radia Nikotyna zamazać i pokazać, że ta rozgłośnia ma wady. Takie sprawy są cicho, a takie osoby są krytykowane, wyszydzane, obśmiewane, że jak tak można. Osoba, która odeszła, to wielki grzesznik, wielki głupiec, tak to wygląda. Albo to tuszują, albo jest to argumentowane, że to nie jest błąd w nas, tylko ta osoba jest po prostu śmieszna (Mikołaj).

To także jedna z przyczyn wspomnianego „balansowania na pograniczu świadomości i nieświadomości”. Część pracowników, zdająca sobie sprawę z nierównego traktowania, nieadekwatnych zarobków czy braku możliwości rozwijania autorskości, stara się przemilczeć tę kwestię, ponieważ wie, że nie ma innej drogi. Wówczas od świadomości taki pracownik wraca z powrotem do nieświadomości, tkwiąc w błędnym kole. Dużą rolę w tym procesie odgrywa także sam mechanizm przyzwyczajenia, określany przez niektórych pracowników jako „zasiedzenie”. Początkowo pracownikom, którzy zaufali marce, odpowiada jej „religia” i rzeczywiście w nią wierzą. Poczucie prestiżu i popularność radia sprawiają, że osoby te odczuwają pewien rodzaj satysfakcji, który przysłania im negatywne elementy, zepchnięte do cienia w procesie „formatowania i budowania identyfikacji”. W momencie, w którym skutki cieni zaczynają być widoczne i pojawia się brak motywacji, poczucie wypalenia, niezadowolenie związane z prezentowaną jakością oraz chęć rozwijania warsztatu czy tworzenia autorskich programów, pracownicy nie mają odwagi do zmiany swojej pozycji bądź otwartych rozmów na ten temat $\mathrm{z}$ innymi członkami organizacji: „raczej o tym też nie rozmawiamy, a jeśli już, to na pewno nie przy zarządzie" (Sara). Ta zasłona milczenia, przyzwyczajenie oraz świadomość, że odejście jest krokiem ostatecznym, potęgują nawarstwianie się cienia organizacyjnego:

Są takie osoby, które nie mają innego świata poza Radiem Nikotyna. Ciężko uciec od tej pracy w życiu prywatnym, masz znajomych z pracy, wszystko się wokół tego kręci. Przez to, że często pracuje się za friko po godzinach, to trudno się zdystansować. To twoje życie. Jak masz je zostawić (Aleksander).

Tak silny emocjonalny związek z organizacją oraz brak dystansu w stosunku do niej jest kluczowym powodem tkwienia w nieświadomości i sprawia, że dostrzeżenie negatywnych stron jest nie tylko trudniejsze, ale i dużo bardziej bolesne. Im większa więź, tym intensywniejsze dążenie do jej idealizowania, nie tylko w kontaktach zewnętrznych, ale przede wszystkim - we własnym umyśle. To właśnie dlatego 
w momencie zauważania cieni pracownicy cały swój wysiłek wkładają w zepchnięcie ich z powrotem do sfery nieświadomości i przykrycie ich grubą warstwą pozytywnych cech, jakie dostrzegają. Ta miłość do organizacji i wiara w jej religię sprawiają, że dochodzi do zjawiska, które określić można jako nie tyle „identyfikację pracownika z organizacją”, co „uzależnienie od miejsca pracy”. Przywiązanie emocjonalne członków badanej instytucji medialnej jest powodem, dla którego została ona określona jako Radio Nikotyna. Użycie metafor w naukach o zarządzaniu rozpropagował Gareth Morgan (2008) w Obrazach organizacji, argumentując, że wykorzystanie ich w opisie instytucji pozwala w sposób uproszczony i przejrzysty oddać jej charakter.

Nikotyna to substancja silnie uzależniająca, powodująca w perspektywie długofalowej szereg negatywnych skutków. Początkowo, choć występuje pewna świadomość jej szkodliwości, ludzie, zwłaszcza młodzi, sięgają po nią, ponieważ wydaje im się ona w jakiś sposób „pociągająca”. Ponadto skutków jej działania nie widać natychmiastowo, tak jak w przypadku innych używek. Z uwagi na to, że destrukcyjny wpływ nikotyny na zdrowie postępuje powoli i jawi się jako proces, to wytwarza się pewnego rodzaju tolerancja. Choć z zewnątrz można usłyszeć głosy mówiące o szkodliwości substancji i jej świadomość się pojawia, to nieumiejętność odstawienia toksyny sprawia, że negatywne skutki są odpychane. Co istotne, jest to także rodzaj uzależnienia społecznego - częstym powodem sięgnięcia po nikotynę jest chęć wyrażenia swojej przynależności do grupy i spędzenia czasu z jej członkami. W końcu, po wielu latach, kiedy negatywne skutki uzależnienia zaczynają być widoczne, okazuje się, że siła przyzwyczajenia jest tak duża, że odstawienie substancji wymaga ogromnej determinacji. Podobny schemat występuje w badanej organizacji. Jej członkowie decydują się na zatrudnienie pomimo świadomości, że praca w niej wiąże się z negatywnymi praktykami. Zepchnięcie do cienia niewygodnych elementów tożsamości sprawia, że ich negatywne konsekwencje nie są odczuwalne od razu; pracownicy powoli zatracają swoje pierwotne wartości, zastępując je wartościami organizacji. Zjawisko potęgowane jest przez dojrzewające przyjaźnie i relacje, których pracownicy nie chcą stracić. Trwają więc w instytucji, konsekwentnie zacieniając wszystkie możliwe wady. Kiedy cień jest już naprawdę złożony, a jego negatywne przejawy zaczynają się unaoczniać, skala przyzwyczajenia jest już tak duża, że trudno im się uwolnić, sprzeciwić i spojrzeć z krytycznej perspektywy. Tak jak w przypadku nikotyny, proces wychodzenia z uzależnienia wymaga determinacji, siły i wsparcia, na co nie każdego stać.

\section{Dyskusja}

Celem powyższego artykułu była eksploracja tematyki cienia organizacyjnego występującego w komercyjnej instytucji medialnej. Przeprowadzone badania już na tym etapie pozwoliły na wyciągnięcie interesujących wniosków i dostarczyły 
istotnej wiedzy z perspektywy nauk o zarządzaniu, jednak poruszana tematyka jest na tyle wielowymiarowa, że należałoby ją pogłębić, wykorzystując odmienne metody badawcze czy prezentując perspektywę innych aktorów społecznych. Cennym uzupełnieniem badań, prowadzącym do wyciągnięcia pełniejszych wniosków, byłoby z pewnością przeprowadzenie obserwacji uczestniczącej ukrytej, obejmującej rozmowy z pracownikami w ich naturalnym środowisku oraz umożliwiającej dostrzeżenie wewnętrznych relacji i spontanicznych zachowań organizacyjnych. Być może należałoby także uzupełnić dotychczasowe badania o antropologiczne wywiady $\mathrm{z}$ byłymi członkami organizacji i analizę porównawczą ich odczuć $\mathrm{z}$ odczuciami obecnych pracowników. Warta rozważenia jest też realizacja rozmów z przedstawicielami zarządu badanej organizacji medialnej, odpowiedzialnymi za strategię rekrutacji, kształcenie pracowników czy politykę wynagrodzeń. Uzyskanie takich informacji pozwoliłoby odpowiedzieć na nurtujące pytania: Czy zarząd jest świadomy skutków istniejących cieni organizacyjnych? Czy próbuje je integrować? Czy podobnie jak pracownicy stara się je wypierać? A może postrzega je jako strategiczną grę i świadomie je ukrywa w celu osiągania większych zysków?

Ciekawym wątkiem tematycznym, godnym rozwinięcia przy wykorzystaniu powyżej zaproponowanych kierunków badań, jest zjawisko „balansowania na granicy świadomości i nieświadomości”. Jak zaznaczał Bowles (1991), cień jest potężną, ale nieświadomą siłą. Przeprowadzona w artykule analiza udowadnia, że cień może być także chwilową domeną świadomości. Stawianie czoła niedoskonałościom organizacji jest wyzwaniem wymagającym ogromnej dojrzałości jej członków. Trudność wynikająca z zauważenia ciemnych stron powoduje, że te spychane są do nieświadomości, której jednak czasem się wymykają. Bezradność w kwestii ich integracji sprawia, że znów są do niej przenoszone. Prowadzi to nie tylko do powstania „błędnego koła cienia" (Kostera 2010, s. 80), skutkującego nawarstwieniem się patologii organizacyjnych, ale także do zjawiska, które można określić mianem „błędnego koła świadomości”, a więc przechodzenia pomiędzy wydobywaniem cienia a jego odpychaniem przy pewnej świadomości tego procesu.

Szczególnie intrygującym obszarem, mogącym stanowić solidną inspirację do dalszych badań, jest jednak kwestia ustalania polityki wynagrodzeń w instytucjach medialnych lub szerzej - w zawodach kreatywnych. Jak pokazuje powyższa analiza, pracownicy Radia Nikotyna kierują się utartym przekonaniem, że zarobki w branży medialnej nie są wysokie, przez co nie próbują walczyć o adekwatne wynagrodzenia, spychając tę kwestię do cienia. Postawę bierności w kontekście walki o współmierne do rynku medialnego pensje wzmaga fakt, że podejmując pracę, członkowie instytucji kierują się pasją, potrzebą satysfakcji i samorealizacji. Są modelowymi przedstawicielami teorii Y (McGregor 1960) i niezależnie od gratyfikacji finansowej starają się wykonywać swoją pracę najlepiej jak tylko umieją, ponieważ ich głównym celem jest zaspokojenie własnych ambicji i idące za tym spełnienie zawodowe. Inaczej sytuacja wygląda w dużych korporacjach, gdzie obowiązki polegają na wykonywaniu 
schematycznych czynności, które trudno określić jako pasjonujące czy też prowadzące do samozadowolenia. Dla pracowników korporacji wysokie zarobki są podstawową motywacją, a więc każda nadprogramowa godzina musi być dodatkowo płatna. Te różnice $\mathrm{w}$ wynagrodzeniu, które często są naprawdę spore, niekoniecznie wynikają z wartości pracy, jej społecznej ważności czy wielkości instytucji. Radio Nikotyna zdaje się bowiem spełniać wszystkie te warunki, a jednak pracownicy wynagradzani są najniższymi możliwymi stawkami w branży medialnej. Pojawia się więc refleksja, czy różnice w zarobkach pomiędzy przedstawicielami zawodów, u podstaw których leży pasja i dążenie do samorealizacji, a pracownikami korporacji, których praca jest rozczłonkowana i schematyczna, nie wynikają z pewnego rodzaju przyzwolenia, a także przekonania, że niezależnie od wysokości zarobków pracownik przykładowej rozgłośni radiowej i tak wykona swoją pracę, nawet jeśli nie otrzyma sprawiedliwej gratyfikacji finansowej. Ustalanie polityki wynagrodzeń w zależności od cech indywidualnych przedstawicieli konkretnych branż może być wartościową kontynuacją przeprowadzonych rozważań. Podjęcie takich badań wiązałoby się z przeprowadzeniem procesu „denaturalizacji”, definiowanej jako „strategia badawcza ukierunkowana na podanie w wątpliwość tych elementów rzeczywistości organizacyjnej, które są powszechnie uznane za naturalne i oczywiste" (Zawadzki 2014, s. 30). Tym oczywistym elementem, jaki należałoby podać w wątpliwość, jest silne przekonanie, że osoby wykonujące zawody określane jako kreatywne powinny zarabiać mniej niż technicy i ścisłowcy, którzy to stali się najbardziej docenianą grupą zawodową. Badania powinny być osadzone w krytycznym nurcie nauki o zarządzaniu, przejawiającym się w dążeniu do troski o człowieka jako uczestnika organizacji. Zastosowanie Critical Management Studies, którego głównymi filarami są denaturalizacja, antyperformatywność oraz refleksyjność, pozwoliłoby na holistyczne zbadanie różnic $\mathrm{w}$ wynagradzaniu pracowników w odniesieniu do ich indywidualnych cech, doprowadzając tym samym do emancypacji, a więc zmiany utrwalonego porządku społecznego.

\section{Zakonczenie}

Przeprowadzone w ramach artykułu badania pozwoliły na eksplorację zjawiska cienia organizacyjnego w instytucji medialnej przy uwzględnieniu jego przyczyn, skutków, a także świadomości poszczególnych aktorów społecznych. Antropologiczne wywiady, stanowiące istotę artykułu, umożliwiły dojście do głosu członkom organizacji, a więc tym, którzy doświadczają jej w najbardziej bezpośredni sposób. W istniejących pozycjach naukowych poruszających tematykę spychania do nieświadomości pewnych elementów organizacji szczególna uwaga poświęcona jest niebezpieczeństwu związanemu z rozwojem cienia w ukryciu, prowadzącym do eksplozji w najmniej oczekiwanym momencie (Bowles 1991, s. 387-404). Wyróżnia się także zjawisko 
nadmiernej kontroli (Carr 2012, s. 477-489), którego celem jest tworzenie idealnego wizerunku na zewnątrz, co w konsekwencji prowadzi do hipokryzji w organizacji oraz nieumiejętności radzenia sobie z ułomnością, będącą domeną każdej instytucji (Kostera 2010, s. 69). Artykuł ukazuje, w jaki sposób te znane w literaturze przedmiotu przejawy cienia organizacyjnego znajdują swoje odzwierciedlenie w komercyjnej instytucji medialnej. Praca porusza wątek nierównego traktowania pracowników wiążącego się z rywalizacją w zawodach medialnych, zgłębia kwestie „formatowania" pracowników wynikającego z komercyjnego charakteru stacji, a także zwraca uwagę na nieadekwatną politykę wynagrodzeń, praktykowaną w popularnej rozgłośni radiowej. W każdym z tych aspektów, będących domeną badanej instytucji medialnej, widać elementy opisywane przez Kosterę (2010), takie jak rezygnacja czy zepsucie. Jak pokazuje przeprowadzona powyżej analiza, główną przyczyną i przyzwoleniem na istnienie i rozwój cieni jest „mit marki” i idące za nim uzależnienie od niej. Mit ten rodzi się w efekcie budowania wewnętrznej tożsamości, opartej na znaczeniu ogólnopolskiej popularności. To szczególnie istotne, jako że w istniejącej literaturze za przyczynę rozwoju cienia podaje się raczej kreowanie wizerunku organizacji na zewnątrz, prowadzące do dysonansu pomiędzy wartościami deklarowanymi a przestrzeganymi, lub też brak poczucia przynależności do organizacji, określany jako miazmat (Kostera 2010, s. 74), co jest zupełnym przeciwieństwem przytoczonych wniosków. Przypadek badanej organizacji pokazuje, że utrwalanie pozytywnego wizerunku w oczach pracowników jest równie niebezpieczne i skutkuje rezygnacją z krytycznego myślenia, prowadząc do zacienienia niewygodnych elementów rzeczywistości społecznej, tym samym wzmagając postawę bierności w kwestii zwalczania patologii zarządzania.

\section{Bibliografia}

Alderfer C. (1972), Existence, Relatedness, and Growth: Human Needs in Organizational Settings, New York: Free Press.

Aleksander A. (2008), Pojęcie identyfikacji pracownika z organizacją w świetle badań literaturowych oraz $w$ praktyce działalności przedsiębiorstw, „Organizacja i Zarządzanie. Kwartalnik naukowy", t. 4, s. 135-149.

Beliczyński J. (2015), Zarządzanie radiem jako subdyscyplina zarządzania mediami, „Studia Medioznawcze", t. 1, nr 60, s. 87-103.

Bowles M.L. (1991), The Organizational Shadow, „Organization Studies”, Vol. 12, No. 3, s. 387-404. Burrell G., Morgan G. (1979), Sociological Paradigms and Organisational Analysis, USA: Ashgate Publishing Company.

Carr A. (2002), Jung, Archetypes and Mirroring in Organizational Change Management: Lessons from a Longitudinal Case Study, „Journal of Organizational Change Management”, Vol. 15, No. 5, s. 477-489. 
Chirkowska-Smolak T. (2009), Organizacyjne czynniki wypalenia zawodowego, „Ruch Prawniczy, Ekonomiczny i Socjologiczny", z. 4, s. 257-272.

Goban-Klas T. (2005), Cywilizacja medialna, Warszawa: Wydawnictwa Szkolne i Pedagogiczne. Gudkova S. (2012), Wywiad w badaniach jakościowych, [w:] D. Jemielniak (red.), Badania jakościowe. Metody i narzędzia, II, Warszawa: Wydawnictwo Naukowe PWN, s. 111-129. Hersey P., Blanchard K.H., Natemeyer W.E. (1979), Situational Leadership, Perception, and the Impact of Power, „Mid-American Journal of Business”, Vol. 12, No. 2, s. 5-12.

Jędrzejewski S. (2003), Radio w komunikacji społecznej. Rola i tendencje rozwojowe, Warszawa: Profi-Press Sp. z o.o.

Jung C.G. (1976), Archetypy i symbole. Pisma wybrane, tłum. J. Prokopiuk, Warszawa: Czytelnik. Klein N. (2009), No Logo, tłum. K. Pustuła, Warszawa: Świat Literacki.

Kociatkiewicz J., Kostera M. (2010), Experiencing the Shadow: Organizational Exclusion and Denial within Experience Economy, „Organization”, Vol. 7, No. 2, s. 257-282.

Kostera M. (1996), Postmodernizm w zarządzaniu, Warszawa: Polskie Wydawnictwo Ekonomiczne. Kostera M. (2000), Zarządzanie personelem, Warszawa: Polskie Wydawnictwo Ekonomiczne. Kostera M. (2003), Antropologia organizacji. Metodologia badań terenowych, Warszawa: Wydawnictwo Naukowe PWN.

Kostera M. (2010), Organizacje i archetypy, Warszawa: Wolters Kluwer.

McGregor D. (1960), The Human Side of Enterprise, New York: McGraw-Hill.

Morgan G. (2008), Obrazy organizacji, tłum. Z. Wiankowska-Ładyga, Warszawa: Wydawnictwo Naukowe PWN.

Nierenberg B. (2011), Zarządzanie mediami. Ujęcie systemowe, Kraków: Wydawnictwo Uniwersytetu Jagiellońskiego.

Picard R.G. (1989), Media Economics: Concepts and Issues, London: SAGE Publications.

Ravasi D., Schultz M. (2006), Responding to Organizational Identity Threats: Exploring the Role of Organizational Culture, „Academy of Management Journal”, Vol. 49, No. 3, s. 433-458. Riesman D. (2011), Samotny tłum, tłum. J. Strzelecki, Kraków: Vis-à-Vis Etiuda.

Sempruch-Krzemińska K. (2014), Symboliczny i społeczny wymiar marki - wpływ na zachowania konsumentów odzieży, „Handel Wewnętrzny”, nr 1 (348), s. 80-88.

Siebert S., Wilson F. (2013), All Work and No Pay: Consequences of Unpaid Work in the Creative Industries, „Work, Employment and Society”, Vol. 4, No. 27, s. 711-727.

Steciąg M. (2006), Informacja, wywiad, felieton. Sposób istnienia tradycyjnych gatunków w radiu komercyjnym, Zielona Góra: Oficyna Wydawnicza Uniwersytetu Zielonogórskiego. Ślufińska P. (2014), Wolontariat jako forma wyzysku pracownika. Autoetnografia pracy wolontariuszki, [w:] Ł. Sułkowski, M. Zawadzki (red.), Krytyczny nurt zarządzania, Warszawa: Difin, s. 195-220. Zawadzki M. (2014), Nurt krytyczny w zarządzaniu. Kultura, edukacja, teoria, Warszawa: Wydawnictwo Akademickie SEDNO. 